\title{
Medicago sativa has Reduced Biomass and Nodulation When Grown with Soil Microbiomes Conditioned to High Phosphorus Inputs
}

\author{
Laura M. Kaminsky, ${ }^{1,2}$ Grant L. Thompson, ${ }^{1}$ Ryan V. Trexler, ${ }^{2}$ Terrence H. Bell, ${ }^{1,2, \dagger}$ and Jenny Kao-Kniffin ${ }^{1}$ \\ ${ }^{1}$ School of Integrative Plant Science, Cornell University, Ithaca, NY; and ${ }^{2}$ Department of Plant Pathology and \\ Environmental Microbiology, The Pennsylvania State University, University Park
}

Accepted for publication 29 August 2018.

\section{ABSTRACT}

Agricultural over-fertilization may adversely impact plant-microbial interactions affecting crop yield. It is unclear if soil microbiomes respond quickly to changes in fertilizer inputs once conditioned to specific nutrient regimes. We conducted a growth chamber study assessing the compositional and functional resilience of root-associated microbiomes of Medicago sativa to nutrient regime changes, and consequences for plant growth. Plants were grown with a common starting soil microbiome under four nutrient treatments: control (no fertilizer), organic phosphorus (compost added), low inorganic $P$ (low triple superphosphate, TSP) and high inorganic $P$ (high TSP). After several conditioning generations, in which microbiomes from rhizospheres of high biomass plants were transferred forward, microbiome composition was distinct across the four treatments. The resulting microbiomes were then transplanted into each of the nutrient treatments, leading generally to functional changes in hydrolytic enzyme activity and taxonomic convergence with other microbiomes transplanted into the same nutrient regime. However, high inorganic P-conditioned microbiomes were resistant to compositional change. Correspondingly, $M$. sativa grown with high inorganic P-conditioned microbiomes had lower biomass, fewer nodules, and lower $\% \mathrm{~N}$ than plants grown under the same nutrient regime with other microbiomes. These findings suggest that excessive inorganic $P$ fertilization may change microbiomes such that they negatively affect plant growth.

Additional keywords: extracellular enzyme activity, nutrient amendments.
The availability of soil nutrients for biological uptake is strongly influenced by the activity of microorganisms, which are key drivers of soil biogeochemical cycles. Soil microorganisms are responsible for the transformation of nitrogen $(\mathrm{N})$ to and from plant-available forms (Ghaly and Ramakrishnan 2015). Some bacteria (e.g., diazotrophs) can fix atmospheric nitrogen into soil, or within root nodules created by certain plant species (Bonilla and Bolanos 2009). Soil bacteria and fungi are critical for the phosphorus $(\mathrm{P})$ cycle, as some solubilize fixed inorganic $\mathrm{P}$ and

${ }^{\dagger}$ Corresponding author: T. H. Bell: E-mail: thb15@psu.edu

Fourth and fifth authors contributed equally.

Funding: This work was supported by the National Institute of Food and Agriculture, U.S. Department of Agriculture (Hatch NYC-145425 to J. Kao-Kniffin) and a Hatch Supplement Program to L. Kaminsky. This work was also funded by the Atkinson Center for a Sustainable Future Postdoctoral Fellowship Program to T. Bell and the College of Agriculture and Life Sciences Alumni Grant Program to L. Kaminsky.

*The $e$-Xtra logo stands for "electronic extra" and indicates that seven supplementary figures and one supplementary table are published online.

(C) 2018 The American Phytopathological Society. mineralize fixed organic $\mathrm{P}$ into the soil solution as plant-accessible phosphate ions (Condron et al. 2005; Pierzynski and McDowell 2005; Nannipieri et al. 2011; Sharma et al. 2013). Certain taxa, known as P-solubilizers, are especially active in this regard, releasing extracellular phosphatases or organic acids that free phosphate ions from complex organic molecules or from adsorption to soil minerals (Nannipieri et al. 2011; Sharma et al. 2013). Additionally, some fungi (e.g., arbuscular mycorrhizal fungi [AMF] and ectomycorrhizal fungi) can help plants scavenge available nutrients from the soil by forming root-connected hyphal networks that extend far beyond plant root hairs into the soil matrix (Jakobsen et al. 2005; Jansa et al. 2011).

Diazotrophs, P-solubilizers, and mycorrhizal fungi have long been studied for their individual impacts on plant growth. In contrast, the wide array of taxa within a soil microbiome may contribute additively to overall nutrient cycling, in ways that are less easily understood and that may vary through time. For example, the soil microbial pool can effectively compete with plants for limiting nutrients, leading to nutrient immobilization within microbial cells. (Jakobsen et al. 2005; Sharma et al. 2013). Upon cell turnover, these nutrients again become bioavailable, which can benefit plant growth. Thus, microbiome dynamics can 
substantially influence plant nutrient acquisition, and subsequently plant growth and health.

In agricultural systems, however, the impact of microbial nutrient cycling on plants can be disrupted by repeated soil nutrient amendments. These inputs, added to enhance crop yield and productivity, can chronically impact soil abiotic properties. For instance, soil $\mathrm{P}$ often accumulates in agricultural fields following repeated applications of inorganic P fertilizers, with 70 to $95 \%$ of applied $\mathrm{P}$ remaining adsorbed to soil particles following plant uptake (Hedley and McLaughlin 2005). Additionally, organic amendments (e.g., manures or composts), when applied to provide adequate $\mathrm{N}$ nutrition, often increase soil $\mathrm{P}$ concentrations far beyond what is needed for plant growth (Nelson and Janke 2007). These fertilizer-induced changes in soil nutrients can impact the composition and function of soil microorganisms. For instance, high levels of soil inorganic $\mathrm{P}$ may suppress AMF root colonization and phosphatase activity, while organic $\mathrm{P}$ may have the opposite effect (Jakobsen et al. 2005; Jansa et al. 2011; Nannipieri et al. 2011; Zhang et al. 2015). Additionally, the abundance of Psolubilizing microbes was shown to decline under high $\mathrm{P}$ availability (Zheng et al. 2017). More broadly, studies from various plant-microbe systems show that microbiome composition and function can change substantially following nutrient additions, although the nature and extent of this change depends on the amendment (Eo and Park 2016; Hartmann et al. 2015; Leff et al. 2015; Li et al. 2017; Pan et al. 2014; Wang et al. 2017).

Different microbiomes can then have measurably different effects on plant traits (e.g., biomass, flowering time, drought tolerance, and disease resistance). These microbiome effects are separate from the direct impacts of abiotic soil properties on plant traits, as determined by the transfer of microbiomes to sterile soils (Lau and Lennon 2012; Mendes et al. 2011; Panke-Buisse et al. 2015; Swenson et al. 2000). In general, such experiments show that if different microbiomes in a comparable environment have measurably different functions, it can be inferred that microbial effects-and not just environmental effects-drive differences in ecosystem function (Allison and Martiny 2008). Thus, if two plants of the same genotype perform differently when grown in comparable soils with

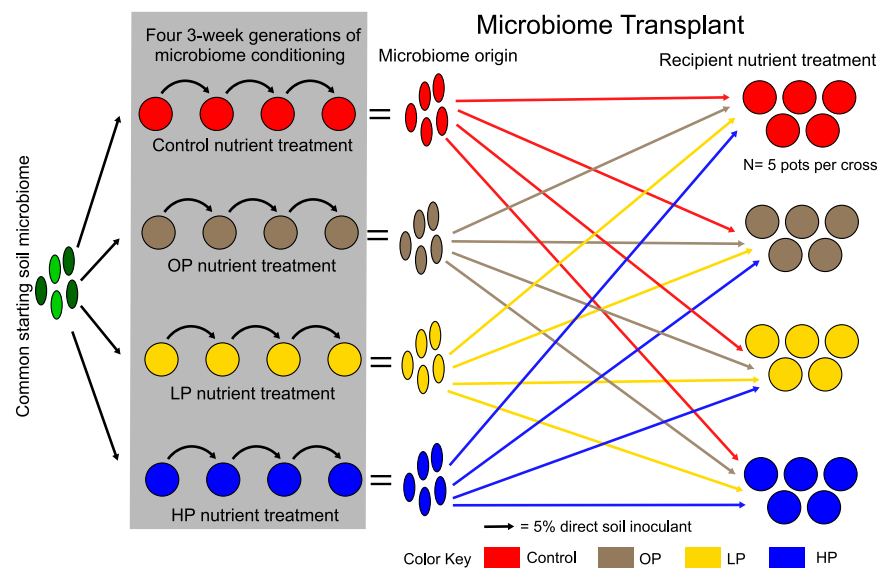

Fig. 1. Experimental design. A common starting soil microbiome was first conditioned to four nutrient input treatments. Table 1 provides descriptions of treatments. Each conditioning generation consisted of 3 weeks of alfalfa. Following plant harvest, replicate pots with the highest biomass were identified and their soil pooled to become the inoculum for the next conditioning generation of the same nutrient treatment. Inoculum collected from generation 4 were then transplanted into all other nutrient treatments, for a total of 16 crosses. different microbiomes, much of that difference should be attributable to microbiome effects.

In this study, we determined whether nutrient-mediated changes to soil microbiome composition and activity were retained under alternate nutrient regimes, and whether this impacted the early growth of alfalfa (Medicago sativa). We conditioned a common starting microbiome to growing with $M$. sativa in one of four soil nutrient input treatments, transferring forward microbiomes from the highest biomass plants for each treatment into twice-autoclaved recipient soils containing the same nutrient treatment, for four generations of conditioning. Following conditioning, microbiomes were again transplanted into twice-autoclaved soils, but this time into each of the four nutrient treatments, yielding sixteen nutrient treatment and microbiome type crosses. We aimed to determine (i) the taxonomic legacy of agricultural nutrient inputs on the soil microbiome when transferred to an alternate nutrient regime, and (ii) the functional legacy of agricultural nutrient inputs on the soil microbiome, particularly with respect to plant performance and soil extracellular enzyme activity (EEA).

\section{MATERIALS AND METHODS}

Experimental design. We aimed to isolate the impacts of microorganisms from the impacts of soil nutrients on plant growth and soil function. We focused primarily on modifying soil $\mathrm{P}$, and chose $M$. sativa (alfalfa), an agriculturally important crop that forms an association with $\mathrm{N}$-fixing rhizobia in root nodules, to reduce the confounding effects of soil $\mathrm{N}$ limitation. We conditioned a common starting microbiome growing with alfalfa to different nutrient input regimes, by selecting microbiomes from pots with the highest aboveground plant biomass and collecting root-adherent soil. These microbiomes were then inoculated into twice autoclaved soil and distributed to the next set of pots, and this was repeated for four 3week generations of plantings. After the fourth generation, the resulting microbiomes were transplanted into each of the four nutrient regimes, yielding 16 nutrient $\times$ microbiome crosses. Figure 1 outlines this design.

Nutrient treatments and growth conditions. Plants were grown in a diverse soil mixture derived from multiple farms and modified to have a more optimal soil texture. The mixture consisted of an $8: 4$ : 2:2:1 ratio of field soil (Williamson sandy loam, a mesic Typic Fragiudept, obtained from the Caldwell Research Farm, Cornell University, Ithaca, NY, $42.45^{\circ} \mathrm{N} 76.46^{\circ} \mathrm{W}$ ), sand, peat moss (Lambert, Rivière-Ouelle, QC, Canada), perlite, and fresh soil from the Helfer Research Farm (Niagara silt loam, a mesic Aeric Endoaqualf, Cornell University, $42.45^{\circ} \mathrm{N} 76.44^{\circ} \mathrm{W}$ ), used as an additional microbial source. To this base soil mix, one of four nutrient treatments was applied: (i) control $(\mathrm{Ct})$, with no nutrient amendments; (ii) organic P (OP), with a compost amendment; (iii) low inorganic P (LP), with a moderate input of triple superphosphate (TSP); and (iv) high inorganic P (HP), with a high input of TSP. Mixture ratios for each treatment are shown in Table 1.

These treatments were designed to differ most in soil $\mathrm{P}$ content while having the same basic physical structure. Samples of each treatment, postmixing, were sent to the Cornell Nutrient Analysis Laboratory (Ithaca, NY) to determine whether other soil parameters varied between treatments (Table 1). Organic matter was determined by loss on ignition, while $\mathrm{pH}$ was measured with a $\mathrm{pH}$ meter in 2:1 water/soil suspensions. Nitrate and ammonium soil concentrations were measured with a potassium chloride extraction. Soil P and K were determined from a modified Morgan's solution extraction. Soil P levels were lowest in the control treatment and highest in the high inorganic $\mathrm{P}$ treatment (Table 1). Soil $\mathrm{pH}$ was not adjusted and therefore varied between treatments; $\mathrm{pH}$ was highest in 
the control treatment and lowest in the high inorganic P treatment (Table 1).

Eighty 6-inch pots (20 replicates per treatment) were filled with $1,400 \mathrm{ml}$ of one of the four nutrient-amended soils. All pots contained a common soil microbiome, consisting of the communities from the two field soils in the base soil mix plus $2 \mathrm{ml}$ of compost slurry (50:1 water/compost), using the compost integrated into the OP treatment as an additional microbial source for the $\mathrm{Ct}$, LP, and HP treatments. M. sativa seeds (Nature's Seed, Lehi, UT) from a common seed pool were surface-sterilized with a $10 \%$ bleach solution for $10 \mathrm{~min}$, rinsed five times with distilled water, added to the pots, and incorporated lightly below the soil surface. Each pot was overseeded and subsequently thinned to 20 plants per pot 4 days after germination, with ongoing removal of any late germinating plants. Plants were grown in the Percival-Cornell University Weill Hall Growth Chamber Facility (Ithaca, NY). Conditions were controlled to a $16 \mathrm{~h} / 8 \mathrm{~h}$ day and night cycle, with temperatures of $30^{\circ} \mathrm{C} / 20^{\circ} \mathrm{C}, 30 \% / 70 \%$ relative humidity, and a light level of $330 \mu \mathrm{E}$. Each pot received $275 \mathrm{ml}$ of autoclaved water every day for 4 days following seeding, and every other day throughout the rest of each growth period.

Plant harvest and soil sampling. Three weeks following germination, all aboveground plant material was harvested and ovendried at $75^{\circ} \mathrm{C}$ for $48 \mathrm{~h}$, and then weighed. The corresponding soil media were stored in bags in a cold room at $4^{\circ} \mathrm{C}$ during this postharvest period to preserve the microbial communities for potential inoculation into the next generation (details provided in "Generation transfer").

Meanwhile, five random pots from each treatment were selected for analyses, to represent the range of microbiome composition and activity in each treatment. Soil was shaken from the root systems of each pot and homogenized individually. A small amount of homogenized media from each sample was collected and frozen. Soil samples from conditioning generations one and four were extracted and sequenced to characterize community changes (details provided in "DNA extraction, PCR amplification, and high-throughput sequencing"), and soil samples from conditioning generation four were additionally assayed for extracellular enzyme activity to characterize community functional differences (details provided in "Soil extracellular enzyme activity").
Generation transfer. The four pots with the highest aboveground plant biomass (i.e., the top $20 \%$ of pots) were identified for each nutrient treatment. Soil from these pots was retrieved from storage, shaken free from plant roots, pooled, and homogenized. This served as the inoculum for the next conditioning generation of the same treatment (Fig. 1).

Dissolved TSP granules and twice-autoclaved compost were mixed into the twice-autoclaved base soil mix in the same ratios as before for each nutrient treatment (Table 1). The prepared soil inoculum was then mixed in at a $5 \%$ inoculum/recipient sterile soil ratio.

This method of microbiome transfer better represents the microbiome structure of the source in the next generation than other commonly used transfer methods, such as soil washes (Howard et al. 2017). Plant growth, harvest, and soil sampling were carried out as described above for each generation, for a total of four generations.

Microbiome transplant. Following the fourth generation, microbiomes conditioned to a specific nutrient regime were transplanted into each of the four nutrient treatments, generating one home-home cross (microbiome introduced to nutrient regime it was adapted to) and three home-away crosses (microbiome introduced to alternate nutrient regimes) for each microbiome type (Fig. 1). Microbial inoculants were prepared for each treatment from the four highest aboveground plant biomass pots as before, but were each divided into four units. Twice-autoclaved soil mixtures were also prepared as before and divided into four units. For each type of inoculant, one unit was mixed with $\mathrm{Ct}$ mixture, another with OP mixture, another with LP mixture, and the last with HP mixture, in the same inoculum to soil ratio as before. That is, each treatment's inoculant was mixed into each treatment's autoclaved mixture, for a total of 16 microbiome-nutrient treatment crosses (Fig. 1). Each cross consisted of five replicate pots, for a total of 80 pots as before. All other aspects of growth and harvest were the same. Soil samples from all 80 pots of the microbiome transplant were extracted and sequenced (details provided in "DNA extraction, PCR amplification, and high-throughput sequencing"), and assayed for extracellular enzyme activity (details provided in "Soil extracellular enzyme activity").

It should be noted that because of the method of inoculation, some soil nutrients were inevitably transferred, as in any direct soil

TABLE 1

Soil media mixture ratios and pH, organic matter, and nutrient properties for the control treatment (Ct), compost amendment treatment (OP), low rate of inorganic $P$ amendment treatment (LP), and high rate of inorganic $P$ amendment treatment (HP) ${ }^{x}$

\begin{tabular}{|c|c|c|c|c|}
\hline Treatment & $\mathrm{Ct}$ & OP & LP & HP \\
\hline Form of $\mathrm{P}$ amendment & None & Compost $^{y}$ & $\begin{array}{l}\text { Dissolved triple superphosphate } \\
\text { (TSP) granules }\end{array}$ & $\begin{array}{l}\text { Dissolved triple superphosphate } \\
\text { (TSP) granules }{ }^{\mathrm{z}}\end{array}$ \\
\hline Amount of amendment added per pot & - & $200 \mathrm{ml}$ & $2.56 \mathrm{~g}$ & $12.79 \mathrm{~g}$ \\
\hline Total amount of soil mix per pot & $1,400 \mathrm{ml}$ & $1,400 \mathrm{ml}$ & $1,400 \mathrm{ml}$ & $1,400 \mathrm{ml}$ \\
\hline Organic matter content & $3.97 \%$ & $4.33 \%$ & $3.40 \%$ & $3.70 \%$ \\
\hline Soil $\mathrm{NO}_{3}+$ soil $\mathrm{NH}_{4}$ & $38.70 \mathrm{ppm}$ & $68.27 \mathrm{ppm}$ & $40.00 \mathrm{ppm}$ & $43.53 \mathrm{ppm}$ \\
\hline Soil $P$ & $12.56 \mathrm{ppm}$ & $82.09 \mathrm{ppm}$ & 174.44 ppm & 741.85 ppm \\
\hline Soil K & 198.50 ppm & $595.92 \mathrm{ppm}$ & 189.59 ppm & 191.80 ppm \\
\hline
\end{tabular}


transfer experiment. That is, each soil mix in the microbiome transplant contained $95 \%$ volume of the recipient nutrient treatment mix plus 5\% inoculant from another nutrient treatment mix with a different nutrient profile. Thus, soil parameters for each of the four crosses in one soil treatment would have been marginally different. We did not specifically measure these differences, but estimates of differing soil $\mathrm{P}$, for which this effect would be most pronounced, can be found in Supplementary Table S1.

Analysis of nodulation. Following soil sampling, all roots from the microbiome transplant pots were rinsed clean and photographed for the purpose of quantifying the number of rhizobial nodules present. Each photograph included all roots from each pot. In Adobe Photoshop CC 2015, the images were manually examined for nodules by imposing a 1 -inch grid over each photo, counting the number of nodules in each grid cell, and summing all grid cell counts (Supplementary Fig. S1).

Analysis of mineral concentration in plant tissues. Following imaging, roots harvested from the microbiome transplant pots were oven dried at $75^{\circ} \mathrm{C}$ for $48 \mathrm{~h}$, then weighed. Dried roots and aboveground biomass from the same replicate were combined using a mortar and pestle, and ground to a fine powder with liquid nitrogen. Combination of root and shoot material was necessary to obtain enough biomass for these analyses. Samples were submitted to the Cornell Stable Isotope Laboratory (Ithaca, NY) for C and N analysis via combustion, and to the Pennsylvania State University Agricultural Analytical Services Lab (University Park, PA) for P analysis via acid digestion.

AMF root colonization. To determine if the AMF symbiosis influenced plant success in this experiment, plant roots from the first generation of conditioning were harvested, stained, and examined for mycorrhizal arbuscules. Cleaned root material (1 to $2 \mathrm{~g}$ ) was cleared in $9 \mathrm{ml}$ of $10 \% \mathrm{KOH}$ at $121^{\circ} \mathrm{C}$ for $5 \mathrm{~min}$. The roots were then rinsed three times and incubated with $10 \mathrm{ml}$ of a trypan blue stain (200 ml each of distilled water, lactic acid, and glycerol, plus $0.15 \mathrm{~g}$ of trypan blue solid) for $24 \mathrm{~h}$ at $25^{\circ} \mathrm{C}$. Stained roots were examined under a dissecting microscope under several magnifications, but no arbuscules were detected in any sample, as AMF colonization was not firmly established in the 3 -week-old $M$. sativa roots. AMF colonization measurements were therefore not conducted for the remainder of the experiment. MiSeq sequencing of the fungal ITS region (details provided in "DNA extraction, PCR amplification, and high-throughput sequencing") later revealed that a very low proportion of the recovered fungal community was classified as Glomeromycota; the highest relative abundance of Glomeromycota in any sample (generation 1, generation 4, and the microbiome transplant generation) was $0.07 \%$, and the majority of samples had no detectable Glomeromycota.

Soil extracellular enzyme activity. Potential extracellular enzyme activities of five hydrolytic enzymes were measured using a standard fluorometric assay (Bell et al. 2013; Panke-Buisse et al. 2015). Briefly, soil slurries were prepared with $3 \mathrm{~g}$ of fresh soil in $150 \mathrm{ml}$ of sodium acetate buffer $(50 \mathrm{mM}, \mathrm{pH} 5)$, homogenized with an immersion blender, and added to black 96-well microplates (200 $\mu \mathrm{l}$ of slurry per well). A second assay was conducted with a sodium carbonate buffer at $\mathrm{pH} \mathrm{7,} \mathrm{as} \mathrm{this} \mathrm{more} \mathrm{closely} \mathrm{represented}$ the in-situ $\mathrm{pH}$ of the $\mathrm{Ct}$ and $\mathrm{OP}$ nutrient treatments. A standard curve was generated for each sample as well as for a buffer blank with known concentrations of 4-methylumbelliferone (MUB). To determine enzyme activity, $50 \mu \mathrm{l}$ of an enzyme-specific substrate bound to MUB was added to the $200 \mu$ l of soil slurry. The substrates were 4-MUB- $\alpha$-D-glucopyranoside, 4-MUB- $\beta$-D-xylopyranoside, 4-MUB- $\beta$-D-glucopyranoside, 4-MUB-N-acetyl- $\beta$-D-glucosaminide, and 4-MUB-phosphate, targeting $\alpha$-glucosidase (AG), $\beta$-xylosidase (BX), $\beta$-glucosidase (BG), $\mathrm{N}$-acetyl glucosaminidase
(NAG), and acid or alkaline phosphatase (AP) enzymes, respectively. Each substrate was also tested for autofluorescence. Following a dark incubation at $25^{\circ} \mathrm{C}$ for $3 \mathrm{~h}$, plates were measured for fluorescence with a BioTek Synergy HT microplate reader (BioTek Industries, Inc., Winooski, VT), at an excitation wavelength of $365 \mathrm{~nm}$ and an emission wavelength of $450 \mathrm{~nm}$.

Enzyme activity was calculated as in (Bell et al. 2013), with some modification. Specifically, sample variability was accounted for not by calculating each sample's MUB concentration from that sample's standard curve, but by correcting the sample fluorescence values for quenching. The average reduction in fluorescence (caused by the interference of soil particles) between points on the sample's standard curve and points on the blank buffer standard curve was calculated, and fluorescence values corrected accordingly. These corrected fluorescence values were then used to calculate MUB concentration in each well from the blank buffer standard curve. Calculations then proceeded normally. This method of calculation better preserved relative fluorescence patterns in the final calculated enzyme activities.

DNA extraction, PCR amplification, and high-throughput sequencing. DNA was extracted from 0.25 to $0.30 \mathrm{~g}$ of soil media using the MoBio PowerSoil DNA Isolation Kit (Mo Bio Laboratories Inc., Carlsbad, CA). Five replicates of the base soil mixture and five replicates of the compost were also extracted.

Initial 16S rRNA gene PCR reactions were carried out as described in Howard et al. (2017), mainly following the 16S Metagenomic Sequencing Library Preparation guide (part no. 15044223 rev. B) with some modifications. The universal bacterial primers 341F (5'-CCTACGGGNGGCWGCAG-3') and 805R (5'-GACTACHVGGGTATCTAATCC-3') were used for $16 \mathrm{~S}$ rRNA gene amplifications (Herlemann et al. 2011), and for fungal amplifications, we used the primers ITS1F (5'-CTTGGTCATTTA GAGGAAGTAA-3') and 58A2R (5'-CTGCGTTCTTCATCGAT$3^{\prime}$ ) (Gardes and Bruns 1993; Martin and Rygiewicz 2005), and all primers were modified to include overhangs needed for index attachment, as described in Bell et al. (2016). For 16S rRNA gene amplifications, reactions occurred in $20 \mu \mathrm{l}$ volumes composed of $8 \mu \mathrm{l}$ of 5 PRIME HotMasterMix (5 PRIME Inc., Gaithersburg, MD), $9 \mu \mathrm{l}$ of $\mathrm{H}_{2} \mathrm{O}, 1 \mu \mathrm{l}$ of each primer at $10 \mu \mathrm{M}$, and $1 \mu \mathrm{l}$ of $1: 10$ DNA dilution. PCR cycling for 16S rRNA gene amplicons was performed using the following protocol: $94^{\circ} \mathrm{C}$ for $2 \mathrm{~min} ; 25$ cycles of $94^{\circ} \mathrm{C}$ for $20 \mathrm{~s}, 55^{\circ} \mathrm{C}$ for $20 \mathrm{~s}$, and $72^{\circ} \mathrm{C}$ for $30 \mathrm{~s}$; and $72^{\circ} \mathrm{C}$ for $5 \mathrm{~min}$ for the final elongation. For fungal ITS amplifications, the reaction mix was as described above, but with $1 \mu \mathrm{l}$ of DMSO and only $8 \mu \mathrm{l}$ of $\mathrm{H}_{2} \mathrm{O}$ per reaction. PCR cycling for fungal ITS amplicons was performed using the following protocol: $94^{\circ} \mathrm{C}$ for 3 min; 35 cycles of $94^{\circ} \mathrm{C}$ for $20 \mathrm{~s}, 45^{\circ} \mathrm{C}$ for $30 \mathrm{~s}$ and $72^{\circ} \mathrm{C}$ for $45 \mathrm{~s}$; with a final elongation at $72^{\circ} \mathrm{C}$ for $5 \mathrm{~min}$.

MagBio HighPrep PCR beads (MagBio Genomics, Gaithersburg, MD) were used to clean the initial amplicons in clear 96-well plates. In new 96-well plates, unique two-barcode index combinations were attached to the cleaned amplicons by placing in each well $5 \mu \mathrm{l}$ of sample, $2.5 \mu \mathrm{l}$ of forward and reverse primers with designated barcodes for overhang attachment, $2.5 \mu \mathrm{l}$ of water, and $12.5 \mu \mathrm{l}$ of Q5 High Fidelity $2 \times$ Master Mix (New England Biolabs Inc., Ipswich, MA). Index attachment PCR cycling conditions were as follows: $98^{\circ} \mathrm{C}$ for $1 \mathrm{~min} ; 8$ cycles of $98^{\circ} \mathrm{C}$ for $15 \mathrm{~s}, 55^{\circ} \mathrm{C}$ for $30 \mathrm{~s}$, and $72^{\circ} \mathrm{C}$ for $20 \mathrm{~s}$; and $72^{\circ} \mathrm{C}$ for $3 \mathrm{~min}$ for final elongation. The SequalPrep Normalization Kit (Thermo Fisher Scientific, Waltham, MA) was then used to normalize the amount of DNA retained from the barcoded amplicons. From each normalized sample, $5 \mu \mathrm{l}$ was combined into separate pools for $16 \mathrm{~S}$ rRNA and ITS genes, concentrated, and run on 1.2\% agarose gels. The PureLink Quick Gel Extraction Kit was used to purify the relevant extracted bands, for a 
final pool volume of $30 \mu \mathrm{l}$. Pools were sequenced at the Cornell Genomics Facility (Ithaca, NY) on the Illumina MiSeq. A 600-cycle MiSeq Reagent Kit v.3 was used for the 16S rRNA gene pool, and a 500 -cycle MiSeq Reagent Kit v.2 for the fungal ITS pool.

Sequence processing and analysis. Initial sequence processing followed the Brazilian Microbiome Project Pipeline (Pylro et al. 2014) with some modifications. In Mothur v.1.36.1 (Schloss et al. 2009), paired-end sequences were merged with make.contigs, primers trimmed with trim.seqs (pdiffs $=2$, maxambig=0), and singleton sequences removed with split.abund. Using USEARCH v.7 (Edgar, 2010), 97\% OTUs were clustered and chimeras removed (based on the $r d p \_g o l d . f a$ database). Using the GreenGenes v. 13.8 database for $16 \mathrm{~S}$ rRNA gene sequences, and the UNITE v.7 database for ITS gene sequences, representative OTUs were classified in Mothur. OTUs suspected not to be of bacterial origin were removed with the command removelineage (taxon=Chloroplast-Mitochondria-unknown-Archaea-Eukaryota).

Further analysis of OTU and taxonomic tables was conducted in $\mathrm{R}$ v. 3.3.2. For all samples, the number of $16 \mathrm{~S}$ rRNA gene sequences was rarefied to 1,004 reads, and the number of ITS sequences was rarefied to 1,421 reads, to normalize intersample comparisons for downstream analyses in R. There was a high proportion of fungal OTUs unclassified at the phylum level, but these were kept in the dataset for further analysis.

Principal coordinates analyses (PCoA) of Bray-Curtis dissimilarities between samples were carried out using $\mathrm{R}$ package vegan to visualize similarity in community composition. Abundance of taxonomic groups was determined using the phyloseq function in the $\mathrm{R}$ phyloseq package. Heatmaps and dendrograms of OTU relative abundance were generated with the function heatmap. 2 in $\mathrm{R}$ package gplots.

Statistical analyses. The lsmeans $\mathrm{R}$ package was used to fit linear models in order to test the effects of nutrient treatment, generation, and the interaction between the two for the conditioning generations, or nutrient treatment, microbiome type, and the interaction between the two for the microbiome transplant. Where needed, data were log-transformed to meet the model assumptions of normality of residuals and homogenous variance. Significance of the models was tested with analysis of variance. Post hoc pairwise comparisons were then using Tukey's honest significant difference test. Pearson correlations and significance of correlation were also tested between data sets.

Sequence availability. All sequences for this study were deposited in the SRA database under the project number SRP133237.

\section{RESULTS}

Bacterial composition post-conditioning. By the end of the four generations of conditioning under a specific nutrient treatment (either control $[\mathrm{Ct}]$, organic phosphorus [OP], low inorganic phosphorus [LP], or high inorganic phosphorus [HP]), distinct bacterial communities were observed in each of the four treatments (Supplementary Fig. S2). HP-conditioned microbiomes were most dissimilar from all other bacterial communities. In generation 1, all microbiomes were more similar to the compost slurry inoculum than the microbiome of the base soil mix, indicating that the compost inoculum was the dominant microbial source for the experiment. Shannon diversity in all treatments declined by generation 4.

Microbiome composition following microbiome transplant. Upon transplant, all microbiomes shifted away from their postconditioning community composition and converged to a community profile that resembled others in the same recipient nutrient treatment (Fig. 2A). However, HP-conditioned microbiomes were resistant to change across all recipient nutrient treatments, and remained most dissimilar from other microbiomes (Fig. 2A). These compositional differences were relatively minor at the phylum/class level, but were clearly observable at the OTU level (Fig. 2B, Supplementary Fig. S3).

Overall, bacterial community composition seemed most influenced by whether or not inorganic fertilizer had been applied, and to what extent, according to the global 16S rRNA gene heatmap (Fig. 2B). Based on unweighted pair-group method with arithmetic mean (UPGMA) hierarchical clustering of Bray-Curtis distances between samples (Fig. 2B), we observed four discrete clusters: (i) bacteria conditioned to the HP nutrient treatment; (ii) bacteria conditioned to other nutrients, but transplanted into the HP nutrient treatment; (iii) bacteria conditioned to the LP nutrient treatment, plus bacteria conditioned to the OP and $\mathrm{Ct}$ nutrient treatments but transplanted into the LP nutrient treatment; (iv) bacteria with no exposure to inorganic $\mathrm{P}$ fertilization at any point in the experiment. Similar clustering patterns were observed at lower taxonomic levels. Fungi showed similar but less resolved patterns in community composition in the microbiome transplant (Supplementary Fig. S4). Fungal communities transplanted into the HP nutrient treatment were very distinct, with a decrease in Basidiomycetes and in increase in Saccharomycetes.

Bacterial families known to contain either P-solubilizers or potential alfalfa $\mathrm{N}$-fixing symbionts had varying abundance patterns in the microbiome transplant. Some groups had lower abundance in microbiomes conditioned to or transplanted into the HP nutrient treatment (Pseudomonadaceae, Comamonadaceae) (Fig. 3). Other groups had higher abundance in microbiomes conditioned to or transplanted into the HP nutrient treatment (Xanthomonadaceae, Burkholderiaceae), while some groups seemed fairly ubiquitous across treatments (Rhizobiaceae, Bacillaceae) (Fig. 3).

Extracellular enzyme activity. Microbially-produced extracellular enzymes in soil are important indicators of $\mathrm{C}, \mathrm{N}$, and $\mathrm{P}$ mineralization from soil organic matter, which allows inorganic $\mathrm{N}$ and $\mathrm{P}$ to be used by plants. As such, these measurements provide a sense of microbiome function and activity. AG, BX, and BG indicate $\mathrm{C}$ mineralization, while $\mathrm{NAG}$ indicates $\mathrm{N}$ mineralization and AP indicates $P$ mineralization (Saiya-Cork et al. 2002). We hypothesized that enzyme activities would be greater under conditions where that nutrient was comparatively limiting in either the soil or the plant, as stoichiometry across soil-microbe-plant systems is often linked (Bell et al. 2014; Xu et al. 2017). Therefore, we expected enzyme activities to be fairly responsive to the change in nutrient treatment in the microbiome transplant. Extracellular enzyme activities were assayed at $\mathrm{pH} 5$ (the standard assay $\mathrm{pH}$ ) and at $\mathrm{pH} 7$ because the soil $\mathrm{pH}$ of the nutrient treatments ranged from 6.12 in the high phosphorus treatment to 7.55 in the control treatment. We wished to measure activities closer to the in-situ $\mathrm{pH}$ for each sample, and hypothesized that activity patterns might be different in the two assays.

We found that all enzyme activities were significantly affected by microbiome origin and nutrient treatment (Fig. 4, Supplementary Fig. S5). That is, most microbiomes of the same origin had significantly different enzyme activities based on which soil they were transplanted into. We observed two general patterns in enzyme activity: (i) activity was highest for microbiomes transplanted into the HP nutrient treatment (Fig. 4A to B); and (ii) activity was highest for microbiomes transplanted into the OP nutrient treatment (Fig. 4C to D). Enzymes displaying pattern 1 included AP, NAG, and $\mathrm{BG}$ assayed at $\mathrm{pH} 5$ (Fig. 4A to B). Enzymes displaying pattern 2 included $\mathrm{AP}, \mathrm{AG}$, and $\mathrm{BX}$ assayed at $\mathrm{pH}$ 7, and $\mathrm{AG}$ assayed at $\mathrm{pH}$ 5 (Fig. 4C to D). Enzymes not falling clearly into either pattern (i.e., displaying activity maxima in either HP or OP nutrient treatments) included $\mathrm{BG}$ and $\mathrm{NAG}$ assayed at $\mathrm{pH} 7$, and $\mathrm{BX}$ assayed at $\mathrm{pH} 5$. 
A

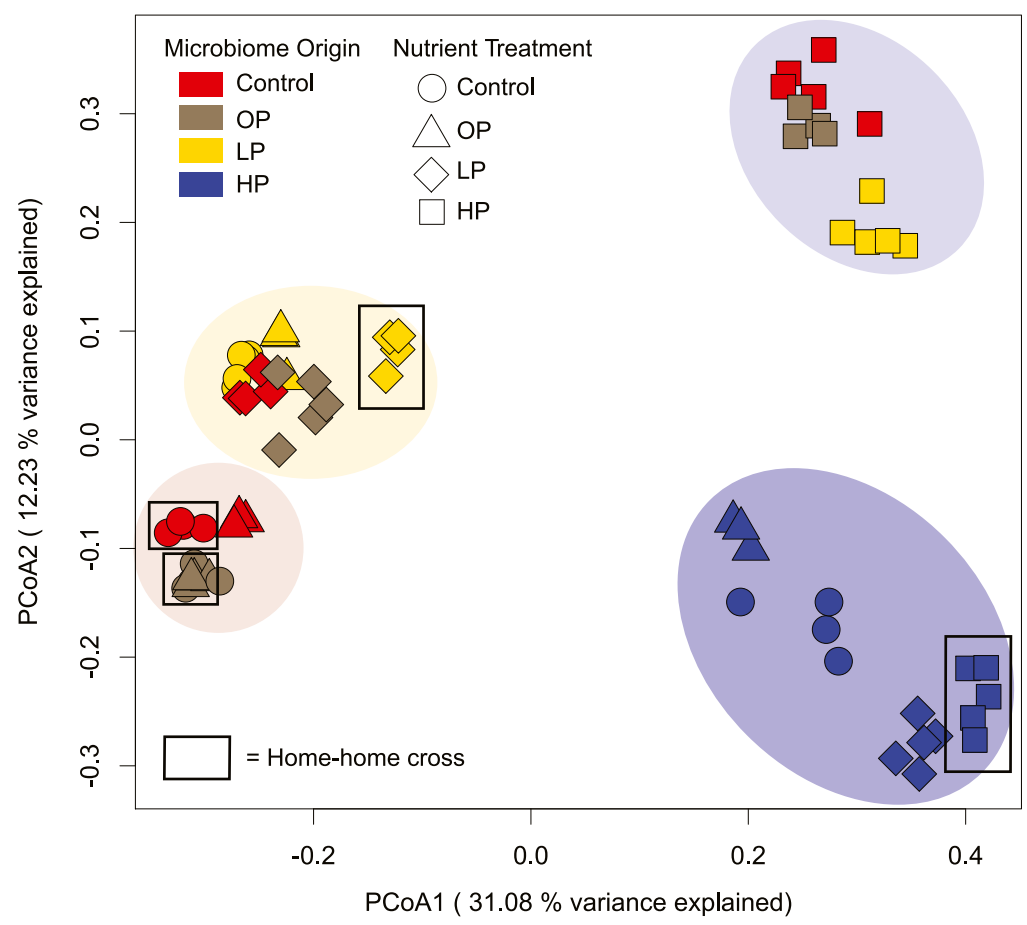

B
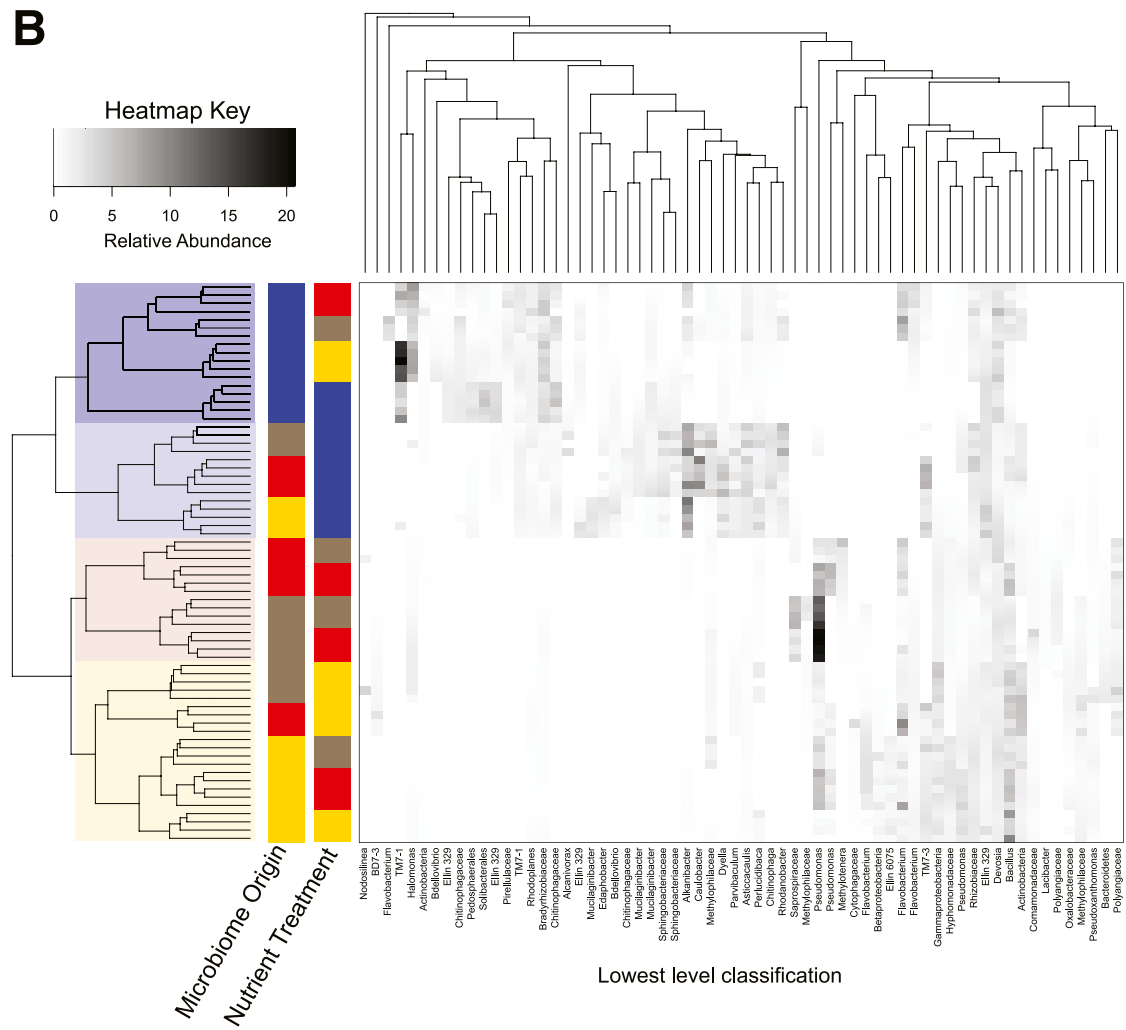

UPGMA-determined sample clusters

Cluster 1 (HP-conditioned microbiomes)

Cluster 2 (Ct, OP, and LP-conditioned microbiomes in the HP nutrient treatment)

Cluster 3 (Ct and OP-conditioned microbiomes in the $\mathrm{Ct}$ or $\mathrm{OP}$ nutrient treatments)

Cluster 4 (LP-conditioned microbiomes in $\mathrm{Ct}, \mathrm{OP}$, or LP nutrient treatments; $\mathrm{Ct}$ and $\mathrm{OP}$-conditioned microbiomes in LP nutrient treatment)

Fig. 2. Soil bacterial community composition in the microbiome transplant. A, Principal coordinates analyses (PCoA) ordination of Bray-Curtis dissimilarities of relative operational taxonomic unit (OTU) abundances generated from 16S rRNA gene amplicons. Point colors reflect the microbiome origin, while point shapes reflect contemporary nutrient treatments. Boxes indicate the points that represent home-home crosses for a given nutrient treatment (e.g., control [Ct]-conditioned microbiomes in Ct treatment soil, organic P [OP]-conditioned microbiomes in OP-amended soil, etc.), to illustrate whether a transplanted microbiome is more similar to those from its native nutrient treatment or to those in the novel nutrient treatment. Shaded ellipses delineated groupings observed based on unweighted pair-group method with arithmetic mean (UPGMA) clustering, and correspond to clusters in panel B. B, Global heatmap of OTU relative abundances for $16 \mathrm{~S}$ rRNA gene amplicons with UPGMA clustering of samples. UPGMA clustering is based on analyses of all OTUs in the dataset, but only bacterial OTUs with at least $2 \%$ relative abundance in at least one sample are shown in the heatmap. Colored bars to the right of the sample dendrogram reflect the microbiome origin and contemporary nutrient treatment of samples. Clusters of samples with similar communities are indicated with colored shading imposed over the sample dendrogram. 
Activity patterns of some enzymes were quite responsive to the assay $\mathrm{pH}$. AP activities switched from pattern 1 at $\mathrm{pH} 5$ to pattern 2 at pH 7 (Fig. 4A and C), as did BG to some extent. Other enzymes, including NAG (Fig. 4B), AG (Fig. 4D), and BX were more consistent in both assays.

M. sativa nodulation, growth, and tissue nutrients. In the four generations of conditioning, there was variability in $M$. sativa aboveground biomass from generation to generation, but generally biomass was highest for plants grown in the OP nutrient treatment, followed by plants grown in the LP nutrient treatment, the $\mathrm{Ct}$ nutrient treatment, and the HP nutrient treatment, in that order (Supplementary Fig. S6). Plants grown in the HP nutrient treatment appeared shorter, had smaller leaves, and were yellowing by the time of harvest (Supplementary Fig. S7).

In the microbiome transplant, $M$. sativa biomass was significantly affected by nutrient treatment and microbiome origin (Fig. 5A to D). Plants grown in the same nutrient treatment with microbiomes conditioned to either Ct, OP, or LP amendments generally showed only minor or insignificant differences in biomass (Fig. 5A to D). Additionally, all plants grew equally well in the OP nutrient treatment regardless of microbial origin (Fig. 5B). However, in the other three nutrient treatments, plants grown with HP-conditioned microbiomes had significantly lower biomass than plants grown with one of the other microbiomes within the same nutrient treatment (Fig. 5A, C, and D).

M. sativa nodulation was also significantly affected by nutrient treatment and microbiome origin (Fig. 5E to H). In the OP, LP, and HP nutrient treatments, plants grown with HP-conditioned microbiomes had significantly lower nodule counts (Fig. 5F to $\mathrm{H})$. In the $\mathrm{Ct}$, OP, and LP nutrient treatments, plants grown with LPconditioned microbiomes had significantly higher nodule counts (Fig. 5E to G). Nodule count was lower for all plants in the HP nutrient treatment, even when plants were grown with microbiomes with which they nodulated well in other nutrient treatments (Fig. $5 \mathrm{H}$ ), suggesting some abiotic limitation on nodulation in the HP nutrient treatment. Nodule count was significantly, positively correlated with aboveground biomass, and significantly, negatively correlated with NAG activity $(P<0.05)$. We suspect this relates to plant nutrient status; plants with more nodules are less likely to be $\mathrm{N}$-limited and may be depositing $\mathrm{N}$ in the soil (Fustec et al. 2011), therefore soil microbes have less need of $\mathrm{N}$ mineralizing-enzymes.
Plants grown in the same nutrient treatment had similar tissue $\% \mathrm{C}$ contents, but tissue $\% \mathrm{~N}$ and tissue $\% \mathrm{P}$ were more variable (Table 2). Plants grown with HP-conditioned microbiomes tended to have a significantly lower tissue $\% \mathrm{~N}$ and significantly higher tissue \% $\mathrm{P}$ than plants grown with other microbiomes in the same nutrient treatment. All plants grown in the HP nutrient treatment had lower tissue $\% \mathrm{~N}$. Nodule counts and plant tissue $\% \mathrm{~N}$ were significantly and positively correlated $(P<0.05)$. Plant tissue $\% \mathrm{P}$ was significantly and positively correlated with estimated soil $\mathrm{P}$ content $(P<0.05)$.

\section{DISCUSSION}

In this study, an initial soil microbiome (derived from agricultural soil and compost) was conditioned to grow with $M$. sativa under four nutrient treatments: no fertilizer (control), organic compost, low inorganic $\mathrm{P}$, and high inorganic $\mathrm{P}$. The four resulting microbiomes were then introduced to each nutrient regime, with $M$. sativa grown under each of the 16 conditions. We aimed to determine the taxonomic and functional resilience of the soil microbiome after different nutrient regimes, and impacts on subsequent plant growth and nodulation.

We note that while microbiomes were conditioned for four generations, they were assessed for legacy effects after only one 3week generation. Thus, observed microbiome responses to new conditions were quite rapid, while observed legacy effects may have broken down over time.

Taxonomic legacy of nutrient conditioning. Soil microbiomes were strongly influenced by conditioning to nutrient treatments. It should be noted that the treatments were not controlled for soil $\mathrm{pH}$ and thus varied simultaneously in $\mathrm{pH}$ and soil $\mathrm{P}$; increasing soil $\mathrm{P}$ was negatively correlated with soil $\mathrm{pH}$ (Table 1 ). Therefore, this study does not determine which of these properties is the driving factor behind the observed differences. However, fertilizer applications to agricultural soils will affect both $\mathrm{pH}$ and soil nutrients at once, and these results are still of practical interest.

Nutrient amendments have been shown to alter bacterial communities at the phylum level (Leff et al. 2015), but we observed clearer differences at lower taxonomic levels. For example, Gammaproteobacteria abundance did not vary substantially between treatments, despite large shifts within this class at the OTU level. We also observed large between-treatment shifts at the family
Groups with lower abundance in UPGMA Clusters 1 and 2

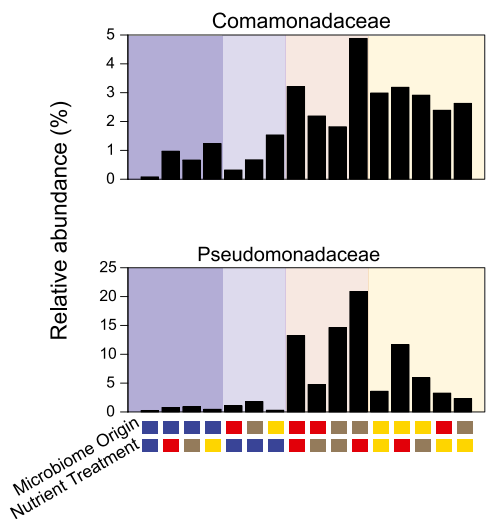

Groups with higher abundance in UPGMA Clusters 1 and 2
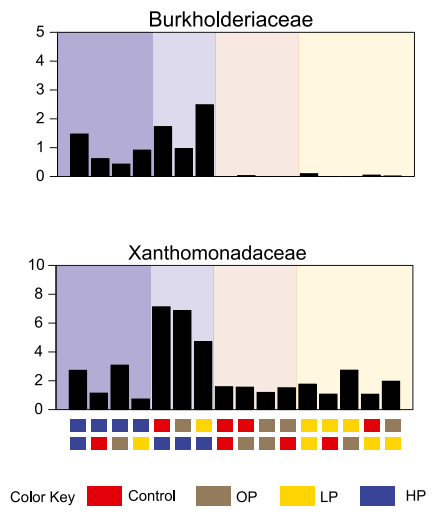

Groups with consistent abundance across UPGMA clusters

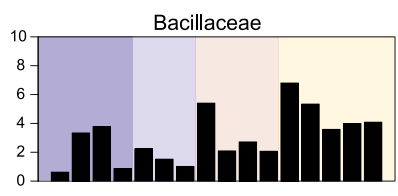

UPGMA-determined sample clusters Cluster 1 (HP-conditioned microbiomes) Cluster 2 ( $\mathrm{Ct}$, OP, and LP-conditioned microbiomes
in the HP nutrient treatment) in the HP nutrient treatment) Cluster 3 (Ct and OP-conditioned microbiomes
in the $\mathrm{Ct}$ or OP nutrient treatments)

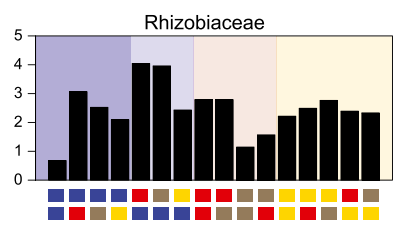
Cluster 4 (LP-conditioned microbiomes in $\mathrm{Ct}, \mathrm{OP}$, or $\mathrm{LP}$ nutrient treatments;
$\mathrm{Ct}$ and $\mathrm{OP}$-conditioned microbiomes in $L P$ nutrient treatment)

Fig. 3. Relative abundances by cross in the microbiome transplant of bacterial families with members identified in the literature as putatively involved in $P$ solubilization or alfalfa nodulation. Colored bars below the panels reflect the microbiome origin and contemporary nutrient treatment of samples. Each bar represents the average family relative abundance for that microbiome origin $\times$ nutrient treatment cross. Samples are grouped based on unweighted pair-group method with arithmetic mean (UPGMA) clustering from Figure 2. 
level for bacteria associated with P-solubilization or nodulation (Fig. 2). Although we cannot definitively assign function to these groups, we hypothesize that these changes also reflect differences in nutrient cycling between treatments.

Following the microbiome transplant, historical legacy-defined as the persistence of biotic conditions created by prior environments (Hawkes and Keitt 2015) —was strongest for HP-conditioned microbiomes, in which taxonomy remained distinct, irrespective of soil nutrient conditions (Fig. 2). The HP nutrient treatment substantially altered the abiotic environment, particularly with respect to soil $\mathrm{pH}$ and $\mathrm{P}$ (Table 1), potentially inhibiting microorganisms that thrive in the other treatments, while promoting those that tolerate high phosphorus loading and a more acidic environment. In contrast, the other treatments may have favored common taxa, while still maintaining a resilient microbial pool that can quickly respond to environmental shifts. We note that, like many microbiome transfer studies, soil compounds were transferred along with microorganisms, leading to slight differences in estimated soil P, and potentially impacting taxonomy to some extent.

We also note that while microbiomes were conditioned for four generations, they were assessed for legacy effects for only three weeks post-transplant. Thus, the time scale of microbiome responses to new conditions was quite short, while observed legacy effects may or may not have persisted in a longer experiment. This would depend on whether nutrient conditioning led to the exclusion of certain microorganisms, or whether it merely shifted the composition of dominant microbes, while allowing other microbes to survive at lower densities.

Functional legacy of nutrient conditioning. We also assessed the functional legacy of nutrient conditioning on soil microbiomes in two ways: (i) plant performance (growth, nodulation, and nutrition); and (ii) EEA.

M. sativa growth negatively affected by HP-conditioned microbiomes. Considered alone, soil abiotic conditions strongly influenced plant growth and nutrition. The $\mathrm{Ct}$ nutrient treatment was likely deficient in soil $\mathrm{P}$ for alfalfa growth; alfalfa biomass plateaus around $20 \mathrm{ppm}$ soil P (Pang et al. 2010) and is considered Pdeficient if plant tissue $\mathrm{P}$ is less than $0.25 \%$ (Lissbrant et al. 2009). $\mathrm{Ct}$ treatment soil contained $12.56 \mathrm{ppm} \mathrm{P}$ (Table 1), and plants grown in the Ct-Ct cross had $0.17 \% \mathrm{P}$ (Table 2). OP and LP nutrient amendments therefore raised soil $\mathrm{P}$ and plant $\% \mathrm{P}$ above deficiency thresholds (Tables 1 and 2), explaining increased biomass in these

\section{Enzyme Pattern 1: \\ A Highest activity in HP nutrient treatment}

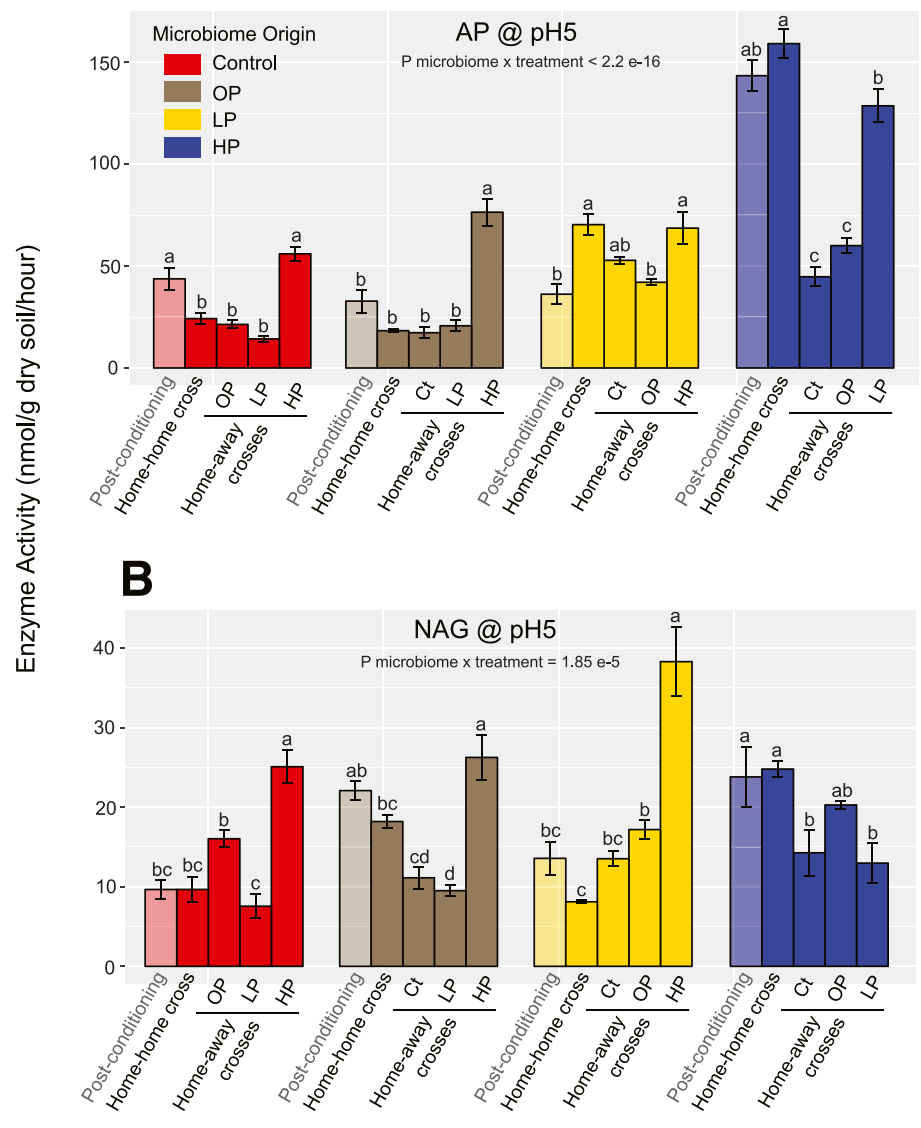

Nutrient Treatment

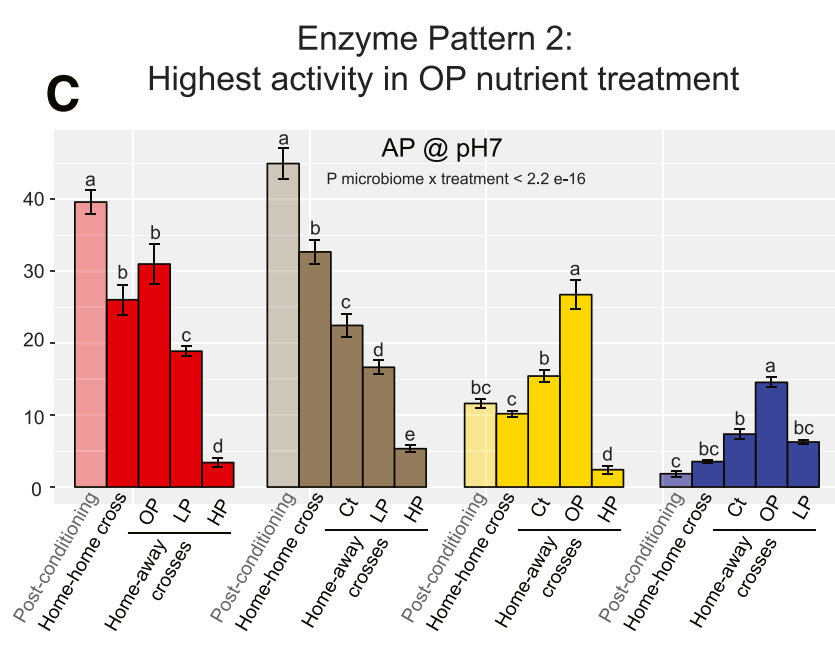

D

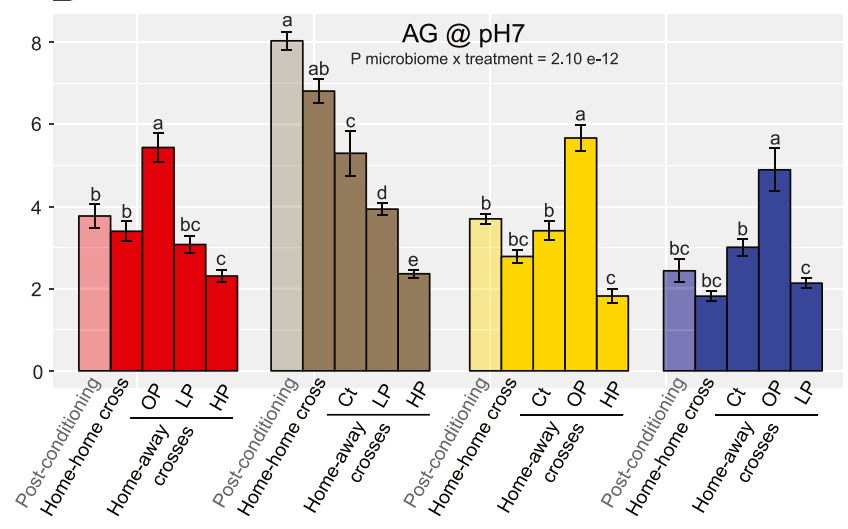

Nutrient Treatment

Fig. 4. Extracellular enzyme activities of generation 4 and microbiome transplant samples. Only a subset of enzymes assayed are displayed here, to demonstrate general activity patterns. Bars represent mean activity \pm standard error. Results are grouped by microbiome origin to reflect microbiome responses to novel nutrient conditions. The home-home cross of the microbiome treatment (e.g., control [Ct]-conditioned microbiomes in Ct treatment soil, organic P [OP]-conditioned microbiomes in OP-amended soil, etc.) always follows the generation 4 bar, then the home-away crosses. Analysis of variance results for each enzyme are displayed at the top of the panel. Letters indicate significant groupings from Tukey's post hoc honest significant difference test. Letters compare results within the same microbiome type, and are therefore not shared through a panel but are specific to the group of four bars they appear with. A, Acid or alkaline phosphatase (AP) activity assayed at pH 5. B, N-acetyl glucosaminidase (NAG) activity assayed at pH 5. C, AP activity assayed at $\mathrm{pH} 7 . \mathrm{D}, \alpha$-Glucosidase (AG) activity assayed at $\mathrm{pH} 7$. 
treatments. However, plant growth was reduced in the HP nutrient treatment. While some plants would experience P toxicity at the soil P levels of the HP nutrient treatment (Pang et al. 2010), the more likely explanation here for biomass reduction is adverse soil $\mathrm{pH}$. The HP nutrient treatment, at a $\mathrm{pH}$ of 6.12 , is close to the threshold $\mathrm{pH}$ at which rhizobia nodulation and $\mathrm{N}$-fixation are impaired for alfalfa (Cheng et al. 2002; Correa et al. 2001; Rice et al. 1977), and plants grown in these soils had significantly reduced nodulation and
$\% \mathrm{~N}$. This was true regardless of microbiome type. Plants grown with the same microbiome had more nodules in the $\mathrm{Ct}$, OP, and LP nutrient treatment than in the HP nutrient treatment. This strongly suggests an abiotic limitation on nodulation success.

Ultimately, however, we were interested in the microbiome effect on plant growth, which would indicate a functional legacy of nutrient conditioning. In the case of $\mathrm{Ct}$, OP, and LP-conditioned microbiomes, community structure rapidly converged when these

\section{Medicago sativa growth in the Microbiome Transplant}
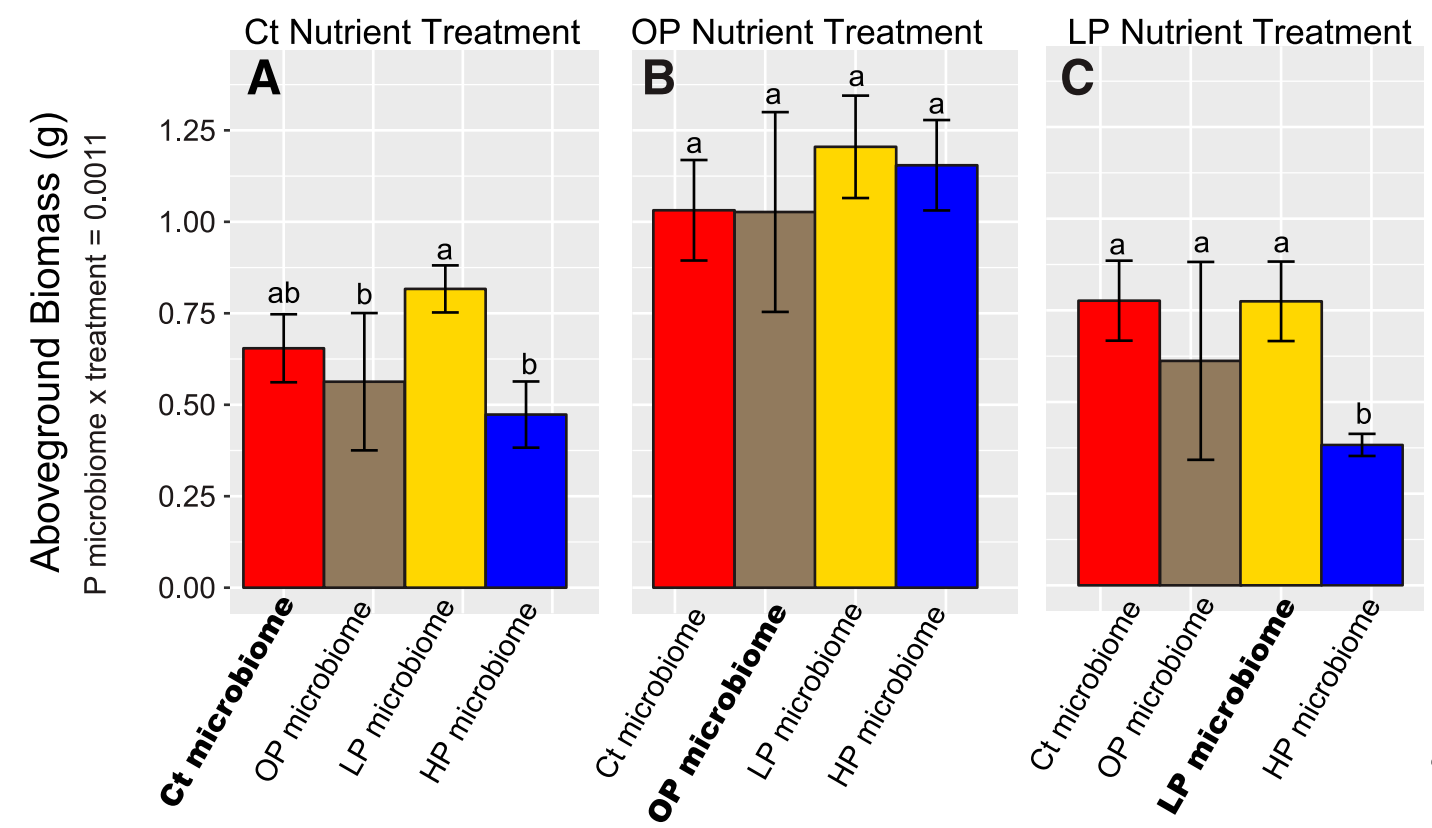

HP Nutrient Treatment
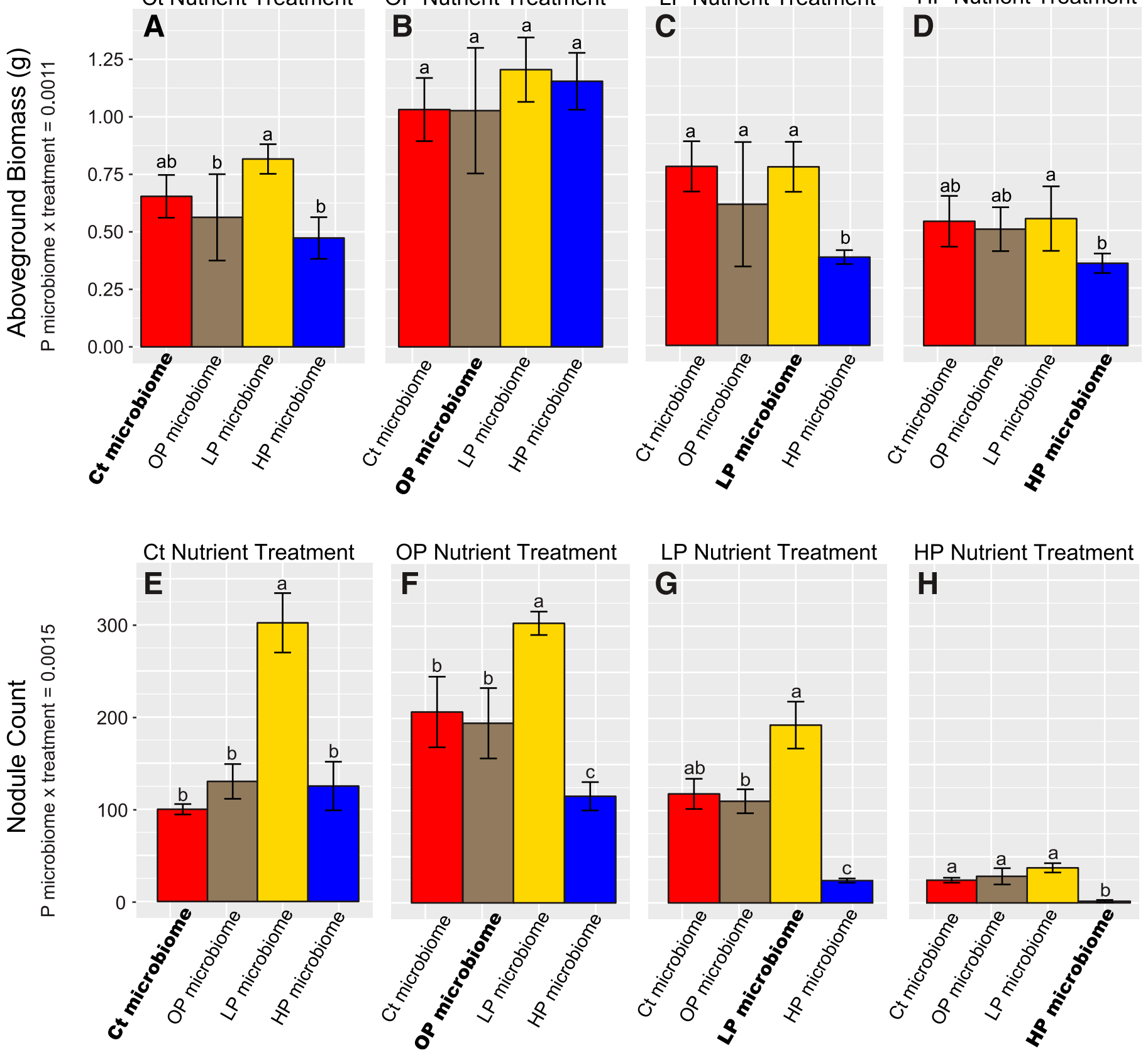

Fig. 5. Alfalfa growth and nodulation in the microbiome transplant. A to D, Aboveground biomass, displayed by nutrient treatment. $\mathbf{E}$ to $\mathbf{H}$, Root nodule raw count, displayed by nutrient treatment. Counts were of nodules on all roots present in a single pot. Bars are colored by microbiome origin and represent mean biomass or nodule count \pm standard error $(n=5)$ for that nutrient treatment-microbiome origin cross. Home-home crosses (e.g., control [Ct]-conditioned microbiomes in Ct treatment soil, organic P [OP]-conditioned microbiomes in OP-amended soil, etc.) are bolded. Analysis of variance results for biomass and nodule count are displayed on the $y$-axes. Letters above bars indicate significant differences in biomass or nodulation by Tukey's honest significant difference test. 
microbiomes were transplanted to the same nutrient treatment. Correspondingly, plants performed equally well as other plants in the same nutrient treatment, regardless of which of these three microbiomes was seeded into the soil. That is, there was little functional legacy.

In contrast, HP-conditioned microbiomes had a clear taxonomic legacy, and correspondingly, plants grown with these microbiomes grew differently from other plants in the same nutrient treatment (Fig. 5, Table 2). This was true even in the native nutrient treatment for HP-conditioned microbiomes. That is, the biotic conditions of the HP microbiome had an observable, adverse effect on plant phenotype, even accounting for the effects of abiotic soil conditions. The mechanism behind the decreased function of the HP-conditioned microbiomes is not clear. Though nodulation was reduced in plants grown with HP-conditioned microbiomes, these microbiomes were not overtly different from $\mathrm{Ct}$, OP, and LP-conditioned microbiomes with respect to the relative abundance of potential nodulating taxa (Fig. 3). However, nodulation success is influenced by many nonrhizobial bacteria (Martínez-Hidalgo and Hirsch 2017), which may include P-solubilizers because nodulation requires sufficient $\mathrm{P}$ nutrition (Kouas et al. 2005). Therefore, the biotic limit on nodulation in HP-conditioned microbiomes may be the result of more complex interactions. Nonetheless, this finding is important; it suggests that microbiome function can degrade in over-fertilized soils. This is not always the case. Significant changes in microbiome composition due to environmental change can occur without corresponding changes in function, due to some functional redundancy among soil microbes or the rapid acclimatization of microbes to new conditions (Hawkes and Keitt 2015; Pan et al. 2014).
Soil extracellular enzyme activities showed adaptation to soil nutrient conditions. Though we found that HP-conditioned microbiomes had a functional legacy with respect to their impact on plant growth, we did not observe a functional legacy for any of our microbiomes related to extracellular enzyme activity. In contrast, our results indicate rapid microbial environmental filtering and/or adaptation in response to nutrient management and/or plant feedback.

As a technical note, our results demonstrate the importance of assay conditions relative to in situ sample conditions, as has previously been discussed (German et al. 2011). We assayed EEA in two $\mathrm{pH}$ buffers to reflect $\mathrm{pH}$ differences in our nutrient treatments. EEA for several hydrolytic enzymes varied by an order of magnitude between $\mathrm{pH} 5$ and $\mathrm{pH} 7$ for some samples, with large changes in relative activity between treatments for certain enzymes (Fig. 4A versus 4C). This reinforces the idea that enzyme activity optima can vary in a soil-specific manner (Turner 2010), which should be addressed by assay conditions.

We observed two general EEA patterns. For AP, NAG, and BG

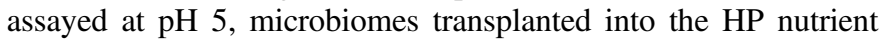
treatment had the highest enzyme activity (Fig. 4A and B). For AP, this pattern likely reflects soil $\mathrm{pH}$. The substrate used for the phosphatase assay can be cleaved by both acid and alkaline phosphatase, which have $\mathrm{pH}$ optima around 4 to 6 and 8 to 10 , respectively (Nannipieri et al. 2011; Turner 2010). Thus, we suspect our pH 5 assay mostly measured acid phosphatase activity, while our pH 7 assay suboptimally measured alkaline phosphatase. High $\mathrm{AP}$ activity measured at $\mathrm{pH} 5$ in the HP nutrient treatment, regardless of microbiome origin, therefore indicates a rapid functional shift; environmental filtering and/or microbial adaptation selected

TABLE 2

Summary of plant tissue nutrient content in the microbiome transplant ${ }^{\mathrm{w}}$

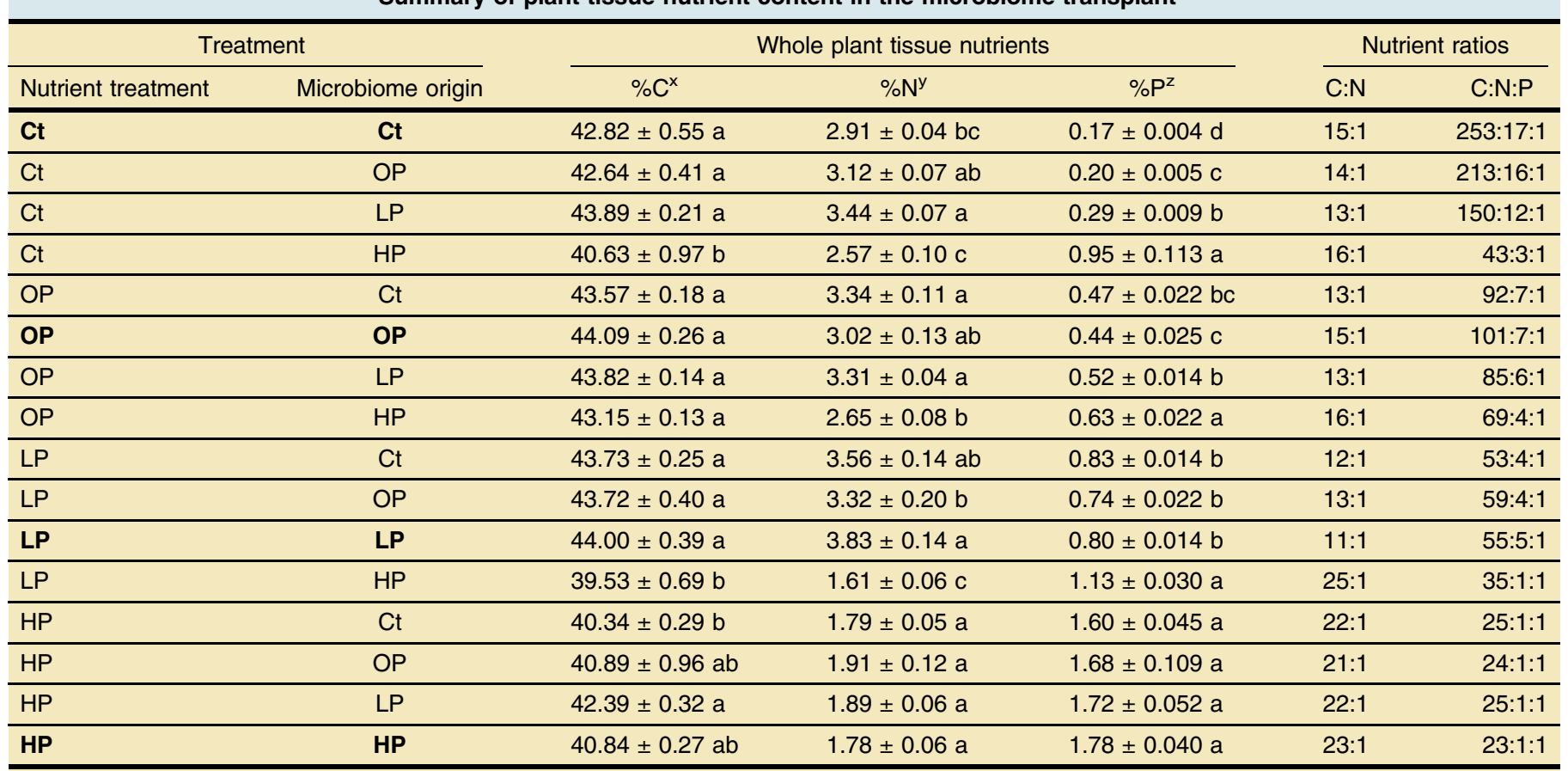

w Nutrient concentration (\% dry weight) in alfalfa plants (pooled shoots and roots) in the microbiome transplant experiment. \%C, \% $\mathrm{N}$, and \%P are displayed as mean $\pm \mathrm{SE}(N=5)$ for that nutrient treatment-microbiome origin cross. Crosses are grouped by nutrient treatment, and bolded crosses indicate the home-home cross for a given nutrient treatment (e.g., control [Ct]-conditioned microbiomes in Ct treatment soil, organic P [OP]-conditioned microbiomes in OP-amended soil, etc.). Letters denote significant differences from Tukey's honest significant difference test. Letters compare results within a single nutrient treatment and are therefore not shared across a column, but are specific to the group of four crosses they appear beside. C: $\mathrm{N}$ and $\mathrm{C}: \mathrm{N}: \mathrm{P}$ were calculated from mean $\% \mathrm{C}, \% \mathrm{~N}$, and $\% \mathrm{P}$ for the cross and rounded to the nearest integers.

$\times \%$ C: $\mathrm{P}$ microbiome $\times$ treatment $=0.00016$.

y $\% \mathrm{~N}: \mathrm{P}$ microbiome $\times$ treatment $<2.2 \mathrm{e}-16$.

$z \% \mathrm{P}: \mathrm{P}$ microbiome $\times$ treatment $<2.2 \mathrm{e}-16$. 
within three weeks for a microbiome that produces phosphatases optimally suited for the in situ soil $\mathrm{pH}$, rather than the $\mathrm{pH}$ of historic nutrient treatments. Mirroring this was AP activity measured at $\mathrm{pH}$ 7 , as activity was highest in the OP nutrient treatment where phosphatases active around $\mathrm{pH} 7$ would be most useful (Fig. 4C).

For NAG assayed at $\mathrm{pH} \mathrm{5,} \mathrm{high} \mathrm{activity} \mathrm{in} \mathrm{the} \mathrm{HP} \mathrm{nutrient}$ treatment may reflect adaptation of a different sort. Generally, legumes can exude soluble $\mathrm{N}$ compounds from their roots (Fustec et al. 2011), a readily available source of $\mathrm{N}$ for soil microorganisms. However, plants grown in the HP nutrient treatment had fewer Nfixing nodules and were N-starved (Fig. 5F, Table 2), and would not likely have deposited as much $\mathrm{N}$ to the rhizosphere as plants grown in other nutrient treatments, making $\mathrm{N}$ more limiting. In such situations, microorganisms may preferentially alter extracellular enzyme release to acquire relatively scarce nutrients (Bell et al. 2014). The increase in NAG activity may thus have been a response to soil $\mathrm{N}$-limitation caused by fewer plant-derived soil $\mathrm{N}$ inputs. A similar explanation may apply to BG assayed at $\mathrm{pH}$, as plants in the HP nutrient treatment showed lower biomass, which may have had decreased $C$ inputs to the rhizosphere (Ikeda et al. 2014).

The second general pattern: for $\mathrm{AP}, \mathrm{AG}$, and $\mathrm{BX}$ assayed at $\mathrm{pH} 7$, and $\mathrm{AG}$ assayed at $\mathrm{pH}$, microbiomes transplanted into the $\mathrm{OP}$ nutrient treatment displayed the highest enzyme activity. AG and $\mathrm{BX}$ are carbon-mineralizing, and activity differences may reflect the fact that only the OP treatment added $\mathrm{C}$ to soil. Microorganisms transplanted to this environment could have increased enzyme production, allowing them to access nutrients that were less available during conditioning. The remaining enzymes do not fit cleanly into either pattern, and enzyme production was likely shaped by multiple factors, or factors not described here.

Conclusions. Soil nutrient amendments quickly and significantly altered the structure and activity of the soil microbiome of alfalfa in this growth chamber experiment. These changes were relatively reversible, especially with regards to extracellular enzyme activity, but a taxonomic legacy effect was observed for microbiomes conditioned to extreme inorganic $\mathrm{P}$ fertilization. $M$. sativa plants had lower biomass and fewer nodules in soils treated with high inorganic $\mathrm{P}$, and when grown in the presence of microbiomes selected under high inorganic $\mathrm{P}$ under most other nutrient conditions. Although the degree of amendment in the high inorganic $\mathrm{P}$ treatment was extreme, this suggests that agricultural amendments resulting in excess soil $\mathrm{P}$ could have adverse impacts on the ability of the soil microbiome to support crop plants, even after changes to soil management.

\section{ACKNOWLEDGMENTS}

Assistance with lab work was provided by members of the KaoKniffin Lab: M. Gannett, L. Wei, O. McCandless, E. Perry, M. Chen, and O. Olawale. We are grateful to L. M. Johnson of the Cornell Statistical Consulting Unit for help with experimental design and statistical analyses.

\section{LITERATURE CITED}

Allison, S. D., and Martiny, J. B. H. 2008. Resistance, resilience, and redundancy in microbial communities. Proc. Natl. Acad. Sci. USA 105: 11512-11519.

Bell, C., Carrillo, Y., Boot, C. M., Rocca, J. D., Pendall, E., and Wallenstein, M. D. 2014. Rhizosphere stoichiometry: Are C: N: P ratios of plants, soils, and enzymes conserved at the plant species-level? New Phytol. 201:505-517.

Bell, C. W., Fricks, B. E., Rocca, J. D., Steinweg, J. M., McMahon, S. K., and Wallenstein, M. D. 2013. High-throughput fluorometric measurement of potential soil extracellular enzyme activities. J. Vis. Exp. 15:e50961.
Bell, T. H., Stefani, F. O. P., Abram, K., Champagne, J., Yergeau, E., Hijri, M., and St-Arnaud, M. 2016. A diverse soil microbiome degrades more crude oil than specialized bacterial assemblages obtained in culture. Appl. Environ. Microbiol. 82:5530-5541.

Bonilla, I., and Bolanos, L. 2009. Mineral nutrition for legume-rhizobia symbiosis: B, Ca, N, P, S, K, Fe, Mo, Co, and Ni: A review. Pages 253-274 in: Organic Farming, Pest Control and Remediation of Soil Pollutants. E. Lichtfouse, ed. Springer, New York.

Cheng, Y., Watkin, E., O'Hara, G., and Howieson, J. 2002. Medicago sativa and Medicago murex differ in the nodulation response to soil acidity. Plant Soil 238:31-39.

Condron, L. M., Turner, B. L., and Cade-Menun, B. J. 2005. Chemistry and dynamics of soil organic phosphorus. Pages 87-121 in: Phosphorus: Agriculture and the Environment. J. T. Sims and A. N. Sharpley, eds. American Society of Agronomy, Crop Science Society of America, and Soil Science Society of America, Madison, WI.

Correa, O., Aranda, A., and Barneix, A. 2001. Effects of pH on growth and nodulation of two forage legumes. J. Plant Nutr. 24:1367-1375.

Edgar, R. C. 2010. Search and clustering orders of magnitude faster than BLAST. Bioinformatics 26:2460-2461.

Eo, J., and Park, K.-C. 2016. Long-term effects of imbalanced fertilization on the composition and diversity of soil bacterial community. Agric. Ecosyst. Environ. 231:176-182.

Fustec, J., Lesuffleur, F., Mahieu, S., and Cliquet, J.-B. 2011. Nitrogen rhizodeposition of legumes. Pages 869-881 in: Sustainable Agriculture, Vol. 2. Springer

Gardes, M., and Bruns, T. D. 1993. ITS primers with enhanced specificity for Basidiomycetes-Application to the identification of mycorrhizae and rusts. Mol. Ecol. 2:113-118.

German, D. P., Weintraub, M. N., Grandy, A. S., Lauber, C. L., Rinkes, Z. L., and Allison, S. D. 2011. Optimization of hydrolytic and oxidative enzyme methods for ecosystem studies. Soil Biol. Biochem. 43:1387-1397.

Ghaly, A., and Ramakrishnan, V. 2015. Nitrogen sources and cycling in the ecosystem and its role in air, water and soil pollution: A critical review. J. Pollut. Eff. Control 3:1-26.

Hartmann, M., Frey, B., Mayer, J., Mäder, P., and Widmer, F. 2015. Distinct soil microbial diversity under long-term organic and conventional farming. ISME J. 9:1177-1194.

Hawkes, C. V., and Keitt, T. H. 2015. Resilience vs. historical contingency in microbial responses to environmental change. Ecol. Lett. 18:612-625.

Hedley, M., and McLaughlin, M. 2005. Reactions of phosphate fertilizers and by-products in soils. Pages 181-252 in: Phosphorus: Agriculture and the Environment. J. T. Sims and A. N. Sharpley, eds. American Society of Agronomy, Crop Science Society of America, and Soil Science Society of America, Madison, WI.

Herlemann, D. P. R., Labrenz, M., Jurgens, K., Bertilsson, S., Waniek, J. J., and Andersson, A. F. 2011. Transitions in bacterial communities along the $2000 \mathrm{~km}$ salinity gradient of the Baltic Sea. ISME J. 5:1571-1579.

Howard, M., Bell, T. H., and Kao-Kniffin, J. 2017. Soil microbiome transfer method affects microbiome composition, including dominant microorganisms, in a novel environment. FEMS Microbiol. Lett. 364.

Ikeda, S., Sasaki, K., Okubo, T., Yamashita, A., Terasawa, K., and Bao, Z. 2014. Low nitrogen fertilization adapts rice root microbiome to low nutrient environment by changing biogeochemical functions. Microbes Environ. 29:50-59.

Jakobsen, I., Leggett, M. E., and Richardson, A. E. 2005. Rhizosphere microorganisms and plant phosphorus uptake. Pages 437-494 in: Phosphorus: Agriculture and the Environment. J. T. Sims and A. N. Sharpley, eds. American Society of Agronomy, Crop Science Society of America, and Soil Science Society of America, Madison, WI.

Jansa, J., Finlay, R., Wallander, H., Smith, F. A., and Smith, S. E. 2011. Role of mycorrhizal symbioses in phosphorus cycling. Pages 137-168 in: Phosphorus in Action: Biological Processes in Soil Phosphorus Cycling. E. K. Bunemann, A. Oberson, and E. Frossard, eds. Springer-Verlag Berlin, Berlin.

Kouas, S., Labidi, N., Debez, A., and Abdelly, C. 2005. Effect of P on nodule formation and $\mathrm{N}$ fixation in bean. Agron. Sustain. Dev. 25:389-393.

Lau, J. A., and Lennon, J. T. 2012. Rapid responses of soil microorganisms improve plant fitness in novel environments. Proc. Natl. Acad. Sci. USA 109:14058-14062.

Leff, J. W., Jones, S. E., Prober, S. M., Barberán, A., Borer, E. T., and Firn, J. L. 2015. Consistent responses of soil microbial communities to elevated nutrient inputs in grasslands across the globe. Proc. Natl. Acad. Sci. USA 112: 10967-10972. 
Li, F., Chen, L., Zhang, J., Yin, J., and Huang, S. 2017. Bacterial community structure after long-term organic and inorganic fertilization reveals important associations between soil nutrients and specific taxa involved in nutrient transformations. Front. Microbiol. 8:187.

Lissbrant, S., Berg, W. K., Volenex, J., Brouder, S., Joem, B., Cunningham, S., and Johnson, K. (2009) Phosphorus and potassium fertilization of alfalfa. Purdue Extension Publication AY-331-W.

Martin, K. J., and Rygiewicz, P. T. 2005. Fungal-specific PCR primers developed for analysis of the ITS region of environmental DNA extracts. BMC Microbiol. 5:28.

Martínez-Hidalgo, P., and Hirsch, A. M. 2017. The nodule microbiome: $\mathrm{N}_{2}$-fixing rhizobia do not live alone. Phytobiomes 1:70-82.

Mendes, R., Kruijt, M., de Bruijn, I., Dekkers, E., van der Voort, M., and Schneider, J. H. M. 2011. Deciphering the rhizosphere microbiome for disease-suppressive bacteria. Science 332:1097-1100.

Nannipieri, P., Giagnoni, L., Landi, L., and Renella, G. 2011. Role of phosphatase enzymes in soil. Pages 215-243 in: Phosphorus in Action: Biological Processes in Soil Phosphorus Cycling. E. K. Bunemann, A. Oberson, and E. Frossard, eds. Springer-Verlag, Berlin.

Nelson, N. O., and Janke, R. R. 2007. Phosphorus sources and management in organic production systems. HortTechnology 17:442-454.

Pan, Y., Cassman, N., de Hollander, M., Mendes, L. W., Korevaar, H., and Geerts, R. H. 2014. Impact of long-term N, P, K, and NPK fertilization on the composition and potential functions of the bacterial community in grassland soil. FEMS Microbiol. Ecol. 90:195-205.

Pang, J. Y., Tibbett, M., Denton, M. D., Lambers, H., Siddique, K. H. M., and Bolland, M. D. A. 2010. Variation in seedling growth of 11 perennial legumes in response to phosphorus supply. Plant Soil 328:133-143.

Panke-Buisse, K., Poole, A. C., Goodrich, J. K., Ley, R. E., and Kao-Kniffin, J. 2015. Selection on soil microbiomes reveals reproducible impacts on plant function. ISME J. 9:980-989.

Pierzynski, G. M., and McDowell, R. W. 2005. Chemistry, cycling, and potential movement of inorganic phosphorus in soils. Pages 53-86 in: Phosphorus: Agriculture and the Environment. J. T. Sims and A. N. Sharpley, eds. American Society of Agronomy, Crop Science Society of America, and Soil Science Society of America, Madison, WI.
Pylro, V. S., Roesch, L. F. W., Ortega, J. M., do Amaral, A. M., Tótola, M. R., and Hirsch, P. R. 2014. Brazilian microbiome project: Revealing the unexplored microbial diversity — challenges and prospects. Microb. Ecol. 67:237-241.

Rice, W., Penney, D., and Nyborg, M. 1977. Effects of soil acidity on rhizobia numbers, nodulation and nitrogen fixation by alfalfa and red clover. Can. J. Soil Sci. 57:197-203.

Saiya-Cork, K. R., Sinsabaugh, R. L., and Zak, D. R. 2002. The effects of long term nitrogen deposition on extracellular enzyme activity in an Acer saccharum forest soil. Soil Biol. Biochem. 34:1309-1315.

Schloss, P. D., Westcott, S. L., Ryabin, T., Hall, J. R., Hartmann, M., and Hollister, E. B. 2009. Introducing mothur: Open-source, platformindependent, community-supported software for describing and comparing microbial communities. Appl. Environ. Microbiol. 75:7537-7541.

Sharma, S. B., Sayyed, R. Z., Trivedi, M. H., and Gobi, T. A. 2013. Phosphate solubilizing microbes: Sustainable approach for managing phosphorus deficiency in agricultural soils. Springerplus 2:587.

Swenson, W., Wilson, D. S., and Elias, R. 2000. Artificial ecosystem selection. Proc. Natl. Acad. Sci. USA 97:9110-9114.

Turner, B. L. 2010. Variation in pH optima of hydrolytic enzyme activities in tropical rain forest soils. Appl. Environ. Microbiol. 76:6485-6493.

Wang, J., Song, Y., Ma, T., Raza, W., Li, J., and Howland, J. G. 2017. Impacts of inorganic and organic fertilization treatments on bacterial and fungal communities in a paddy soil. Appl. Soil Ecol. 112:42-50.

Xu, Z., Yu, G., Zhang, X., He, N., Wang, Q., and Wang, S. 2017. Soil enzyme activity and stoichiometry in forest ecosystems along the North-South transect in eastern China (NSTEC). Soil Biol. Biochem. 104:152-163.

Zhang, X. Y., Dong, W. Y., Dai, X. Q., Schaeffer, S., Yang, F. T., and Radosevich, M. 2015. Responses of absolute and specific soil enzyme activities to long term additions of organic and mineral fertilizer. Sci. Total Environ. 536:59-67.

Zheng, B.-X., Hao, X.-L., Ding, K., Zhou, G.-W., Chen, Q.-L., Zhang, J.-B., and Zhu, Y.-G. 2017. Long-term nitrogen fertilization decreased the abundance of inorganic phosphate solubilizing bacteria in an alkaline soil. Sci. Rep. 7:42284. 